\title{
ROLE OF SOCIAL SUPPORT TOWARD STUDENT ACADEMIC SELF-EFFICACY IN ONLINE LEARNING DURING PANDEMIC
}

\author{
Wahyu Saefudin', Sriwiyanti2*, Siti Hajar Mohamad Yusoff ${ }^{3}$ \\ 1-3Sultan Zainal Abidin University, Malaysia \\ ${ }^{1}$ wahyusae1992@gmail.com, 22sriwiyanti1993@gmail.com.* \\ 3shajarmy@unisza.edu.my
}

\begin{abstract}
The Covid-19 pandemic has changed many government policies. The online learning policy reaps various negative responses, including doubt and anxiety in students regarding academic success. Students need high self-confidence or self-efficacy to attend learning suitably and produce the desired results. Therefore, this study aims to describe the description of student self-efficacy and its role in establishing online learning success and the social support contribution to student academic self-efficacy. The research method used is a qualitative approach with the primary data in a literature review collected through various search pages for scientific journals, books, and government regulations. Data analysis used descriptive analysis by describing the research results in illustration form. The study results explain that some students' academic self-efficacy is high, and others are in the middle to lower category. Then, sources of social support, such as parental support, teacher support, close friend support, and classmate support, affect online learning. In addition, social support has a decisive role in enhancing students' academic self-efficacy. Thus, this research can be used as an evaluation material in education and a reference in making policies.

Keywords: Social Support; Academic Self-Efficacy; Online Learning; Covid-19 Pandemic.
\end{abstract}

\section{INTRODUCTION}

Many countries transform from traditional learning to emergency online learning during Covid-19. However, many students remain to respond to it negatively. For example, in New Zealand, 39\% of students reported difficulty maintaining motivation during their studies. It is caused by instructors' or peers' help inaccessibility (Yates et al., 2021). In addition, United Emirates Arabs obtained criticism from students such as; cost and time effectiveness issues, safety users, low participation, the uncomfortable environment that reduced focus during the learning, problems in using the technology, and insufficient support from teachers and colleagues (Hussein et al., 2020). Parents in Hongkong also complain about low satisfaction with online 
Saefudin, W., Sriwiyanti, Yusof, S.H.M. (2021). ROLE OF SOCIAL SUPPORT TOWARD STUDENT ACADEMIC SELF-EFFICACY IN ONLINE LEARNING DURING PANDEMIC. Jurnal Tatsqif, 19 (2), 133-154. https://doi.org/10.20414/itq.v19i2.4221

learning programs because they encounter challenges during their involvement in children's education (Lau et al., 2021).

In addition, a study by Permatasari et al. (2021) revealed that pandemics and the complex transformation of traditional learning to online learning have resulted in academic burnout; it was caused by feelings of tiredness, cynicism, separation from education, and inadequacy. However, a student with high self-efficacy will decrease academic burnout intention. Therefore, students need academic self-efficacy during online learning. A study by Pellerone (2021) also supports that self-efficacy decreased burnout and other negative behaviors during learning, such as procrastination attitudes. As a result, students will be more confident and perform suitably in an assignment (Svartdal et al., 2021; Tuaputimain, 2021).

Furthermore, during the pandemic, self-efficacy has a significant role in the online learning process, so students undergo advanced learning even under challenging conditions (Cahyani \& Winata, 2020). Therefore, students with self-efficacy will be more focused on studying and completing a task (Pantu, 2021b). Thus, they will also avoid plagiarism in finishing their assignments (Anitasari et al., 2021).

The importance of academic self-efficacy in online learning during pandemics, this study describes academic self-efficacy and academic level of self-efficacy increasing factors. One influencing variable is social support that will stimulate students' performance adequately during online learning modalities (Tus, 2021). For example, most family support provides instrumental support for students such as technology, the internet, and other convenient circumstances. Moreover, peer groups such as close friends' and classmates' support remain essential because social issues are obstacles to online learning programs, especially in facing isolation and physical distancing challenges (Lemay et al., 2021). Finally, teachers' support through empathy, authenticity, and providing emotional and informational support on the platform will help students flourish in their education (Literat, 2021). 
Furthermore, the role of social support toward academic self-efficacy is distinguished. Social support will increase the confidence in completing the academic demands (Akanni \& Oduaran, 2018). Another study in the online learning context revealed that social support was identified as a partial mediating factor for self-efficacy (Zhou \& Yu, 2021). In addition, a higher level of social support will encourage students to achieve higher achievement with education than those with lower perceived social support (Achour \& Nor, 2014). In comparison, students who perceived a lack of social support were more likely to suffer academic stress (Wistarini \& Marheni, 2018).

In conclusion, students who had passed transition emergency from traditional learning to online learning are experiencing numerous obstacles. However, significant gaps remain in investigating the solution related to this problem, especially social support and self-efficacy issues. Moreover, it was not straightforward to uncover studies related to online learning that concentrated on self-efficacy, specifically related to online learning success in the context of pandemic Covid-19. Some studies only focused on analyzing the advantages and disadvantages and the challenges and opportunities of online learning during the pandemic (Adedoyin \& Soykan, 2020; Alghamdi et al., 2020). While this study focuses on discovering the description of academic self-efficacy, the role of social support in online learning, and social support toward academic self-efficacy during the pandemic.

\section{LITERATURE REVIEW}

\section{Online Learning During Pandemic}

Online learning is defined in four main ideas. First, it utilizes technology in presenting education. Second, it provides asynchronous instruction in multiple ways. Third, the characteristic of online learning is an interactive discussion that requires high cooperation from students and teachers. Finally, it is involved physical distancing (Singh \& Thurman, 2019). However, the pandemic constructs a different structure because many elements in 
Saefudin, W., Sriwiyanti, Yusof, S.H.M. (2021). ROLE OF SOCIAL SUPPORT TOWARD STUDENT ACADEMIC SELF-EFFICACY IN ONLINE LEARNING DURING PANDEMIC. Jurnal Tatsqif, 19 (2), 133-154. https://doi.org/10.20414/itq.v19i2.4221

education are striving to adjust to this emergency regulation. It also results in various consequences between students, particularly regarding the government's lack of preparation and socialization (Adedoyin \& Soykan, 2020).

During a pandemic, students encounter many obstacles and distractions in online learning, especially internet connection problems (Abou-Khalil et al., 2021). In addition, a study revealed that $51.7 \%$ of the population suffers academic stress from many aspects, such as psychological, physiological, and cognitive aspects that count as a high category (Indriani, 2021). Therefore, online learning in a pandemic requires convenience, support, and high service quality (Jin et al., 2021).

\section{Social Support}

Social support is the extent to which individuals believe that they are trusted and loved, appreciated, and became a member of a mutual system. Supportive interactions among people pose a protective factor from chaos or pathological cases (Cobb, 1976). In addition, an adequate level of support will reduce stress and any others symptomatology (Winemiller et al., 1987). Moreover, a study by Cohen and Wills (1985) distinguished the association between social support and people's general well-being.

Nonetheless, those definitions are mainly raised from clinical issues. As for the educational context, social support is a robust behavior for children and adolescents in school environments to advance in education. For instance, social support from various sources provides help to the students in adjusting to problematic issues and learning difficulties (Malecki \& Elliot, 1999). Moreover, social support contributes significantly to diminished school maladjustment. It has also become a solution for some of the most complex academic procrastination, plagiarism, and skipping school (Demaray \& Malecki, 2002).

Specifically, there are four sources of social support for students in an 
educational context: support from parents, teachers, classmates, and close friends (Malecki \& Demaray, 2002). In addition, there are four aspects of social support. The following are detailed descriptions:

1. Emotional Support

Emotional support defines as being emotionally present to someone when they need us. It demonstrated various emotional types as support, such as trust, caring, compassion, love, acceptance, and intimate interaction (Tardy, 1985).

2. Instrumental Support

Instrumental support defines as a helping behavior in various forms, such as lending money, helping in a difficult situation, spending time together, and affording materials needed. When necessary, it also involves practical help and providing tangible assistance such as bringing tools (Wills \& Shinar, 2000).

3. Informational Support

Informational support is defined as providing knowledge or advice to someone (Malecki \& Demaray, 2003). For example, they give precious insight as a problem solving, presenting information related to the problem, providing guidance in many alternatives, and advising effectiveness to more appropriate circumstances.

4. Appraisal Support

Appraisal support is defined as contributing evaluative feedback and supplying rewards in many ways, such as delivering verbal affirmation, stating praise, and stating feedback regarding progress (Birch, 1998). It also provides constructive critique or evaluative suggestions as a method of self-evaluation.

\section{Academic Self-Efficacy}

The self-efficacy concept was proposed by Bandura (1977) as a combination of self-reliance, self-confidence, and trust in oneself. Self-efficacy 
Saefudin, W., Sriwiyanti, Yusof, S.H.M. (2021). ROLE OF SOCIAL SUPPORT TOWARD STUDENT ACADEMIC SELF-EFFICACY IN ONLINE LEARNING DURING PANDEMIC. Jurnal Tatsqif, 19 (2), 133-154. https://doi.org/10.20414/itq.v19i2.4221

is not how a person likes himself or how much someone appreciates any given task, but self-efficacy is how confident a person is to achieve the expected outcomes (Malkoç \& Mutlu, 2018). In other words, self-efficacy is a person's judgment on his ability to produce and carry out behaviors leading to getting specific goals (Bandura, 1977, 1997). In education, self-efficacy is one of the essential keys to creating student achievement in the educational process (Cahyani \& Winata, 2020). Academic self-efficacy is defined from Bandura's self-efficacy theory, that is, an individual belief (conviction) that they can successfully perform at a designated level on an academic assignment or attain a specific academic purpose (Luszczynska et al., 2005; Prihastyanti \& Sawitri, 2018; Schunk \& Pajares, 2002).

Bandura (1977) declares that in social learning analysis, expectations of personal efficacy are based on four critical sources of learning: performance accomplishments, physiological states, vicarious experience, and verbal persuasion. Shofia (2021) declares that these four sources of efficacy could be condensed into a hierarchy. Performing repetitive tasks is the most potent source because it is based on first learning. Thus, a person can instantly know whether he has endured success or failure. The other three sources are all based on indirect information. Self-efficacy also influences behaviors and environments (Bandura, 1997). Schunk and Dibenedetto (2016) argue that self-efficacy influences students in three behaviors: self-regulation, learning motivation, and achievement. For example, students who feel more prosperous in learning should be more likely to engage in self-directed learning. In turn, self-efficacy can be affected by behavioral results such as progress and goal attainment and environmental inputs such as feedback from teachers, support from the parents, and social connections with peers. 


\section{EFFICACY EXPECTATIONS}

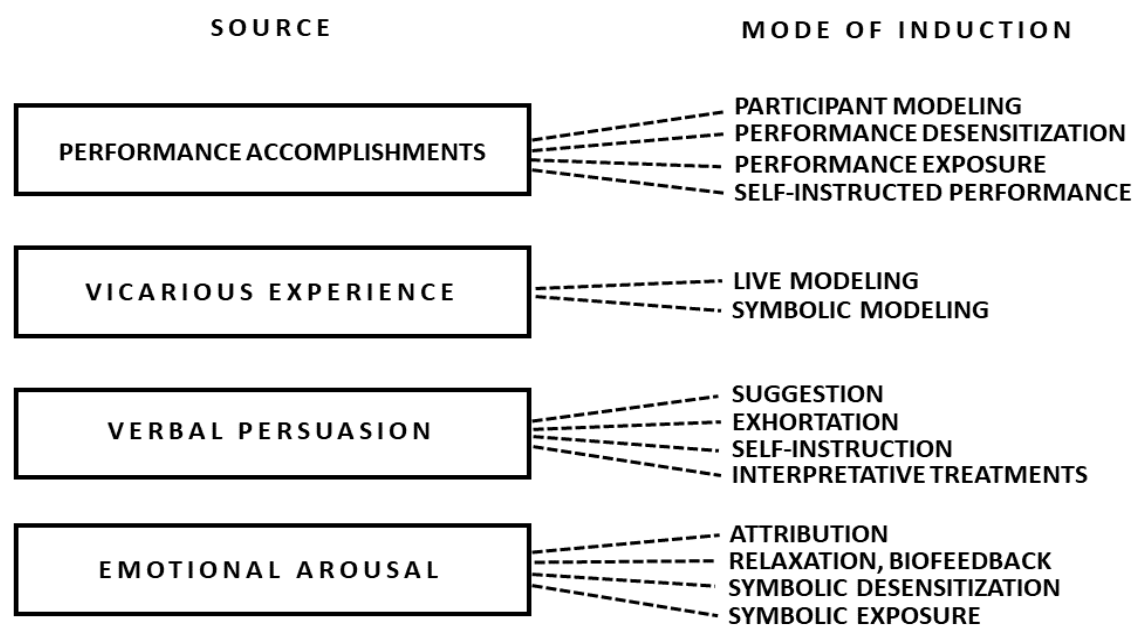

Figure 1. Major Sources of Efficacy Information and the Principal Sources through which Different Modes of Treatment Operate.

\section{METHODOLOGY}

This study employs qualitative methods through a literature review technique. This method is primarily focused on collecting various research sources such as journals, books, official government websites, and published reports as data sources (Sugiyono, 2018). In addition, literature review studies can be carried out when the research objectives have been determined clearly. In addition, secondary data sources support the analysis and answer the research problems (Zed, 2014). Moreover, this study has satisfying data sources related to social support and self-efficacy in online learning. Therefore, the literature review approach is suitable for describing an analysis related to the research problem.

Furthermore, the data collection procedure in this study consists of multiple-stage, e.g., determining the problem and research topic, collecting data from various resources such as Elsevier, Science Direct, Google Scholar, Scopus, Taylor, and Francis Online, e-resources national library, and ProQuest. The keywords used in the search include online learning during the pandemic, social support, self-efficacy, and academic self-efficacy. 
In addition, the study analysis applies descriptive analysis techniques that describe the finding narratively. The descriptive is to answer three research questions: how the description of self-efficacy in online learning during a pandemic; how is the role of social support in online learning during a pandemic; and how is the role of social support toward self-efficacy in online learning during the pandemic.

\section{FINDING AND DISCUSSION}

\section{The Description of Academic Self-Efficacy in Online Learning During Pandemic}

In the online learning context, academic self-efficacy has been studied with various variables in research, including motivation, academic success, procrastination, academic flow, academic resilience, and academic burnout (Erdianto \& Dewi, 2020; Pantu, 2021b; Permatasari, Sutanto, et al., 2021; Svartdal et al., 2021). From these various studies, academic self-efficacy can be a robust predictor in influencing other variables. Consequently, students need academic self-efficacy abilities due to the various challenges they face in online learning. For example, the transformation of learning from face-to-face to online learning affected providing the material that is not optimal, and anxiety cannot follow lessons, stress, and depression (Lemay et al., 2021; Tsuroya, 2020). However, online learning also has various positive impacts, such as avoiding Covid-19, not encountering learning loss, and students adapting to new technology (Yazid \& Neviyarni, 2021). Therefore, students must have high academic self-efficacy to avoid the negative impacts of online learning.

Various studies on academic self-efficacy during a pandemic confirm the critical role of academic self-efficacy for students. Academic self-efficacy can enhance academic performance during online learning. This research means that if a student's academic self-efficacy is high, the student will also get high academic results (Yokoyama, 2019). Academic self-efficacy influences 
Saefudin, W., Sriwiyanti, Yusof, S.H.M. (2021). ROLE OF SOCIAL SUPPORT TOWARD STUDENT ACADEMIC SELF-EFFICACY IN ONLINE LEARNING DURING PANDEMIC. Jurnal Tatsqif, 19 (2), 133-154. https://doi.org/10.20414/itq.v19i2.4221

academic performance in online learning and a more general context, precisely in face-to-face learning conditions (Honicke \& Broadbent, 2016). The impact of academic self-efficacy on academic performance is so high because students with high academic self-efficacy also tend not to experience academic procrastination (Khotimatussannah et al., 2021; Li et al., 2020; Malkoç \& Mutlu, 2018; Rahmadina et al., 2020). In addition, students with high academic self-efficacy also have an academic flow to focus on completing the tasks given during online learning (Pantu, 2021b).

However, students' academic self-efficacy in online learning is not always at a high level. Erdianto and Dewi (2020) research show that 35.8\% or 62 students have academic self-efficacy in the medium category. Likewise, Fadilah and Rafsanjani (2021) researched 85 respondents of the study, 33\%, or 28 respondents, in the lower to middle category. In addition, the research conducted by Yuri and Yendi (2020) also strengthens previous research. Research conducted on 31 respondents, only 19\% are in the high and very high categories. While the rest, 81\%, are in the lower to middle category. Another study conducted by Pantu (2021a) also explained that the higher the semester students, the lower their academic self-efficacy.

\section{The Role of Social Support in Online Learning During Pandemic}

Reviewing the role of social support during online learning is necessary to describe three primary objectives. First, it determines the most influential source of support for students in online learning. Second, it showed students' perceived social support levels so that many elements could improve their support. Third, it decides which supporting aspects become a more prominent role in online learning during the pandemic, such as emotional, instrumental, informational, and appraisal support.

In addition, a different source of support will display different form functions. For example, most familial support provides instrumental support for students such as technology, the internet, and other convenient 
Saefudin, W., Sriwiyanti, Yusof, S.H.M. (2021). ROLE OF SOCIAL SUPPORT TOWARD STUDENT ACADEMIC SELF-EFFICACY IN ONLINE LEARNING DURING PANDEMIC. Jurnal Tatsqif, 19 (2), 133-154. https://doi.org/10.20414/itq.v19i2.4221

circumstances during learning. Therefore, it is the most influencing source of support in students' learning progress (Permatasari, Ashari, et al., 2021). Specifically, parents provide emotional support in learning through their involvement. This form of participation has a positive role in adolescent commitment and perseverance toward online learning. Therefore, parents should synergize with the digital revolution and provide direct guidance to children (Lawrence \& Fakuade, 2021). Additionally, parents' support in learning will enhance performance during a hard adjustment in a pandemic (Tus, 2021). Thus, parents also should provide high emotional support.

Furthermore, peer groups such as close friends' and classmates' support remain essential because social issues are obstacles to online learning programs. Especially in facing the challenges of isolation in physical distancing regulation during the lockdown (Lemay et al., 2021). At the same time, students need direct interaction and face-to-face bonding with friends and classmates. A study found that students were more engaged during the Question and Answer session in online learning. It was shown that students seemed to be active when they knew that their friends were also online. It was become a strengthen factor during the study (Jansson et al., 2021). Therefore, friends' support is considered positively influential for students to keep high participation in education.

Finally, teachers' support also enhances the experience in online learning. Some studies revealed that students believe that teachers' support through empathy, authenticity, and providing emotional and informational support on the platform will help them flourish in their education (Literat, 2021). Moreover, bonding with the teacher will remain a strength when teachers can utilize social media. In addition, it will become fundamental support during emergencies online learning, where face-to-face opportunities are decreased (Jogezai et al., 2021).

In conclusion, every source of support has a varied role in online learning programs. It is further associated with the different aspects provided. For 
Saefudin, W., Sriwiyanti, Yusof, S.H.M. (2021). ROLE OF SOCIAL SUPPORT TOWARD STUDENT ACADEMIC SELF-EFFICACY IN ONLINE LEARNING DURING PANDEMIC. Jurnal Tatsqif, 19 (2), 133-154. https://doi.org/10.20414/itq.v19i2.4221

example, parents are expected to provide emotional and instrumental support through supplying learning material and being involved as emotional support in the children's learning processes. As for friends, students were intended to receive emotional support that satisfies the need to socialize with others. While teachers provide extensive support, they develop informational and appraisal support that accommodates the knowledge and evaluative feedback.

\section{The Role of Social Support Toward Academic Self-Efficacy in Online Learning During Pandemic}

There must be an effort to increase students' academic self-efficacy in online learning. Academic self-efficacy will affect choices, goals, reactions, emotions, efforts, adjustments, and rejections in undergoing academic demands. If students' academic self-efficacy is high, they will be calmer and have a more positive perspective on online learning. Meanwhile, students with low academic self-efficacy lack self-confidence, doubt themselves, and avoid complicated tasks given in online learning (Permatasari, Sutanto, et al., 2021). Therefore, it is crucial to discover the factors or variables influencing academic self-efficacy to advance online learning.

Social support will become an impactful event in individuals' lives and influence students' motivation to thrive the academic difficulty. A study found that perceived social support is positively related to academic selfefficacy, even it is not mediated by the adjustment process in education and life satisfaction. However, social support will increase the confidence in completing the academic demands (Akanni \& Oduaran, 2018). Another study in the online learning context revealed that social support is positively associated with home-quarantined Chinese college students' online learning self-efficacy and well-being. Social support was identified as a partial mediating factor of online-learning self-efficacy (Zhou \& Yu, 2021).

In addition, a higher level of social support will encourage students to 
Saefudin, W., Sriwiyanti, Yusof, S.H.M. (2021). ROLE OF SOCIAL SUPPORT TOWARD STUDENT ACADEMIC SELF-EFFICACY IN ONLINE LEARNING DURING PANDEMIC. Jurnal Tatsqif, 19 (2), 133-154. https://doi.org/10.20414/itq.v19i2.4221

achieve higher achievement with education than those students with lower perceived social support. It is further necessary for students to adjust and become more prosperous in life (Achour \& Nor, 2014). In comparison, students who perceived a lack of social support were more likely to be slightly severely depressed, associated with aspects of burnout, including an increased risk of experiencing emotional exhaustion or having a sense of low personal accomplishment. Moreover, students who lack social support tend to experience academic stress (Wistarini \& Marheni, 2018).

In addition, various sources of support have different roles in forming student academic self-efficacy. However, these resources may also perform it to serve as a team. For example, positive collaboration between teachers, parents, and school psychologists appears beneficial for students. Schools that have developed successful partnership programs between parents and teachers significantly improve students' efficacy (Kourkoutas et al., 2015).

Besides, students who received more detailed feedback significantly increased their self-efficacy. It is further categorized as appraisal support when it becomes the opportunity to discover students learning progress through evaluation and appreciation (Peechapol et al., 2018). However, providing accommodations and positive beliefs to students was not sufficient to increase students' academic self-efficacy. They need strong support from institutional, familial, and peers (Mana et al., 2020). In conclusion, between aspects of social support and source of support will present a different function toward self-efficacy. Therefore, this study describes respective sources and aspects of social support toward academic self-efficacy.

First, perceived family support had significant positive associations with academic self-efficacy. It further will lead to positive effects on motivations (Bagci, 2018). Another study presented that parents' educational aspirations for their children (informational and appraisal supports) stood out as a powerful positive predictor for adolescents' academic self-efficacy, engagement and, intrinsic motivation in learning. This finding indicates that 
Saefudin, W., Sriwiyanti, Yusof, S.H.M. (2021). ROLE OF SOCIAL SUPPORT TOWARD STUDENT ACADEMIC SELF-EFFICACY IN ONLINE LEARNING DURING PANDEMIC. Jurnal Tatsqif, 19 (2), 133-154. https://doi.org/10.20414/itq.v19i2.4221

students who perceived that their parents appreciated their education and had high expectations for their academic success could feel interested, engaged, and convinced towards their academic challenges (Fan \& Williams, 2010).

Second, peer relationships and interactions are acknowledged as crucial for enhancing the quality of education and student learning. Especially peers support provides liking and belonging in a social relationship (Hughes \& Chen, 2011). It is also a reciprocal cycle benefit because the more students are perceived as helpful and preferred as collaboration co-workers by many others at the beginning of the semester, the more they are proposed to discuss personal issues or friendship (Zander et al., 2018).

Third, high motivation students are affected by teachers' support through the mediation of academic self-efficacy (Liu et al., 2017). High onlinelearner interaction between students, content, and teacher are likely to demonstrate higher self-efficacy for education and satisfaction with the course. Therefore, teacher professional development programs that present didactic instruction and modeling in creating a positive social-emotional context will improve the educational achievement of all students (Hughes \& Chen, 2011).

Finally, all stakeholders of online education, such as students, teachers, institutions, society, and parents, pose a crucial role in its implementation. Educators and developers operating online should create engaging lessons as a form of support, especially for the millions of first-generation and young participants of online education who possess low self-confidence in their abilities (Kundu, 2020). Therefore, even multiple sources of social support have their respective role. However, these all were required to increase academic self-efficacy to advance in the online learning program.

\section{CONCLUSION}

The discussion above explains that student academic self-efficacy during 
online learning does not flourish, even in some studies in the lower middle category. At the same time, high academic self-efficacy influences students' ability to strive in online learning. Meanwhile, the level of academic selfefficacy that is causing individual belief (conviction) is not optimal; consequently, they cannot optimally perform at a designated level on an academic assignment or attain a specific academic purpose. Additionally, every source of social support has a different role during online learning. For example, parents are expected to produce emotional and instrumental support by supplying learning material and being involved as emotional support in the children's learning processes. As for friends, students intend to obtain emotional support that satisfies the need to socialize with others. While teachers support the majority comes up with informational and appraisal support that accommodates the knowledge and evaluative feedback. In addition, social support is a variable that significantly affects academic self-efficacy during online learning. Moreover, four sources of social support are parental support, teacher support, close friend support, and classmate support, which influence academic self-efficacy. Therefore, outstanding support from the four sources of social support is needed for students' academic self-efficacy to be high.

Furthermore, this research has implications for three sectors. First, the government can utilize this study's results as a policy regulator to publish policies to enhance student success in online learning. Second, as a policy material for schools to encourage support from teachers and fellow students in the learning process. Finally, this study's results will assist parents in providing support to students to complete student requirements and maximize learning outcomes.

\section{REFERENCES}

Abou-Khalil, V., Helou, S., Khalifé, E., Chen, M. A., Majumdar, R., \& Ogata, H. (2021). Emergency Online Learning in Low-resource Settings: Effective 
Student engagement Strategies. Education Sciences, 11(1), 1-18. https://doi.org/10.3390/educsci11010024

Achour, M., \& Nor, M. R. M. (2014). The Effects of Social Support and Resilience on Life Satisfaction of Secondary School Students. Journal of Academic and Applied Studies, 4(January), 12-20. www.academians.org Adedoyin, O. B., \& Soykan, E. (2020). Covid-19 Pandemic and Online Learning: the Challenges and Opportunities. Interactive Learning Environments, 1-14. https://doi.org/10.1080/10494820.2020.1813180 Akanni, A. A., \& Oduaran, C. A. (2018). Perceived Social Support and Life Satisfaction among Freshmen: Mediating Roles of Academic Self-efficacy and Academic Adjustment. Journal of Psychology in Africa, 28(2), 89-93. https://doi.org/10.1080/14330237.2018.1454582

Alghamdi, A., Karpinski, A. C., Lepp, A., \& Barkley, J. (2020). Online and faceto-face classroom multitasking and academic performance: Moderated mediation with self-efficacy for self-regulated learning and gender. Computers in Human Behavior, 102(August 2019), 214-222. https://doi.org/10.1016/j.chb.2019.08.018

Anitasari, A., Pandansari, O., Susanti, R., Kurniawati, K., \& Aziz, A. (2021). Pengaruh Efikasi Diri terhadap Perilaku Menyontek Siswa Sekolah Dasar selama Pembelajaran Daring. Jurnal Penelitian Ilmu Pendidikan, 14(1), 82-90. https://doi.org/10.21831/jpipfip.v14i1.37661

Bagci, S. C. (2018). Does Everyone Benefit Equally From Self-Efficacy Beliefs? The Moderating Role of Perceived Social Support on Motivation. Journal of Early Adolescence, 38(2), 204-219. https://doi.org/10.1177/0272431616665213

Bandura, A. (1977). Self-Efficacy: Toward a Unifying Theory of Behavioral Change. Psychological Review, 84(2), 191-215. https://doi.org/https://psycnet.apa.org/doi/10.1037/0033295X.84.2.191

Bandura, A. (1997). Self-Efficacy: The Exercise of Control. In W. H. Freeman 
and Company. W. H. Freeman and Company.

Birch, D. (1998). Identifying Source of Social Support. The Journal of School Health, 68(4).

Cahyani, N., \& Winata, H. (2020). The Roles of Self-Efficacy and Discipline in Improving Students' Learning Outcomes. Jurnal Pendidikan Manajemen Perkantoran, 5(2), 234-249. https://doi.org/10.17509/jpm.v4i2.18008

Cobb, S. (1976). Social Support as a Moderator of Life Stress. Psychosomatic Medicine, 38(5), 300-313.

Cohen, S., \& Wills, T. A. (1985). Stress, Social Support, and the Buffering Hypothesis. Psychological Bulletin, 98(2), 310-357. https://doi.org/10.1037/0033-2909.98.2.310

Demaray, M. K., \& Malecki, C. K. (2002). The Relationship between Perceived Social Support and Maladjustment for Students at Risk. Psychology in the Schools, 39(3), 305-316. https://doi.org/10.1002/pits.10018

Erdianto, A. A., \& Dewi, D. K. (2020). Hubungan Antara Efikasi Diri Dengan Prokrastinasi Akademik Pada Siswa Kelas XI Di SMA X. Character: Jurnal Penelitian Psikologi., 8(8), 32-43.

Fadilah, R. N., \& Rafsanjani, M. A. (2021). Pengaruh Efikasi Diri Siswa Terhadap Hasil Belajar Ekonomi Dalam Pembelajaran Daring. Jurnal Paradigma Ekonomika, 16(3), 581-588.

Fan, W., \& Williams, C. M. (2010). The Effects of Parental Involvement on Students' Academic Self-efficacy, Engagement, and Intrinsic Motivation. Education Psychology, 3410. https://doi.org/10.1080/01443410903353302

Honicke, T., \& Broadbent, J. (2016). The Influence of Academic Self-Efficacy on Academic Performance: A Systematic Review. Educational Research Review, 17, 63-84. https://doi.org/10.1016/j.edurev.2015.11.002

Hughes, J. N., \& Chen, Q. (2011). Reciprocal Effects of Student-teacher and Student-peer Relatedness: Effects on Academic Self-efficacy. Journal of Applied Developmental Psychology, 32(5), 278-287. 
https://doi.org/10.1016/j.appdev.2010.03.005

Hussein, E., Daoud, S., Alrabaiah, H., \& Badawi, R. (2020). Exploring Undergraduate Students' Attitudes towards Emergency Online Learning during COVID-19: A Case from the UAE. Children and Youth Services Review, 105699. https://doi.org/10.1016/j.childyouth.2020.105699

Indriani, T. (2021). Gambaran Stres Akademik Saat Pembelajaran Jarak Jauh

(Pjj) Pada Siswa Di Smk Negeri 1 Godean Tahun Pelajaran 2020/2021.

Ristekdik: Jurnal Bimbingan Dan Konseling, 6(1), 1. https://doi.org/10.31604/ristekdik.2021.v6i1.1-6

Jansson, M., Hrastinski, S., Stenbom, S., \& Enoksson, F. (2021). Online Question and Answer Sessions: How Students Support Their Own and Other Students' Processes of Inquiry in a Text-Based Learning Environment. Internet and Higher Education, 51(December 2020), 1-10. https://doi.org/10.1016/j.iheduc.2021.100817

Jin, Y. Q., Lin, C. L., Zhao, Q., Yu, S. W., \& Su, Y. S. (2021). A Study on Traditional Teaching Method Transferring to E-Learning Under the Covid-19 Pandemic: From Chinese Students' Perspectives. Frontiers in Psychology, 12(March), 1-14. https://doi.org/10.3389/fpsyg.2021.632787

Jogezai, N. A., Baloch, F. A., Jaffar, M., Shah, T., Khilji, G. K., \& Bashir, S. (2021). Teachers' Attitudes towards Social Media (SM) Use in Online Learning amid the COVID-19 Pandemic: the Effects of SM Use by Teachers and Religious Scholars during Physical Distancing. Heliyon, 7(4), 1-9. https://doi.org/10.1016/j.heliyon.2021.e06781

Khotimatussannah, N., Khairunisya, N., Pitaliki, T., \& Anggraeni, A. (2021). Pengaruh Efikasi Diri Terhadap Penyesuaian Akademik Di masa Pembelajaran Online Pada Mahasiswa Universitas Muhammadiyah Bandung. Jurnal Sosial Dan Humaniora, 3(1), 29-36.

Kourkoutas, E., Eleftherakis, T. G., Vitalaki, E., \& Hart, A. (2015). FamilySchool-Professionals Partnerships: An Action Research Program to Enhance the Social, Emotional, and Academic Resilience of Children at 
Saefudin, W., Sriwiyanti, Yusof, S.H.M. (2021). ROLE OF SOCIAL SUPPORT TOWARD STUDENT ACADEMIC SELF-EFFICACY IN ONLINE LEARNING DURING PANDEMIC. Jurnal Tatsqif, 19 (2), 133-154. https://doi.org/10.20414/itq.v19i2.4221

Risk. Journal of Education and Learning, 4(3), 112-122. https://doi.org/10.5539/jel.v4n3p112

Kundu, A. (2020). Toward a Framework for Strengthening Participants' Selfefficacy in Online Education. Asian Association of Open Universities Journal, 15(3), 351-370. https://doi.org/10.1108/aaouj-06-2020-0039

Lau, E. Y. H., Li, J. Bin, \& Lee, K. (2021). Online Learning and Parent Satisfaction during COVID-19: Child Competence in Independent Learning as a Moderator. Early Education and Development, 32(6), 830842. https://doi.org/10.1080/10409289.2021.1950451

Lawrence, K. C., \& Fakuade, O. V. (2021). Parental Involvement, Learning Participation, and Online Learning Commitment of Adolescent Learners during the COVID-19 Lockdown. Research in Learning Technology, 29, 116.

Lemay, D. J., Bazelais, P., \& Doleck, T. (2021). Computers in Human Behavior Reports Transition to Online Learning during the COVID-19 Pandemic. Computers in Human Behavior Reports, 4.

Li, L., Gao, H., \& Xu, Y. (2020). The Mediating and Buffering Effect of Academic Self-Efficacy on the Relationship between Smartphone Addiction and Academic Procrastination. Computers \& Education, 159(August), 1-11. https://doi.org/10.1016/j.compedu.2020.104001

Literat, I. (2021). "Teachers Act Like We're Robots": TikTok as a Window Into Youth Experiences of Online Learning During COVID-19. AERA Open, 7(1), 233285842199553. https://doi.org/10.1177/2332858421995537

Liu, R. De, Zhen, R., Ding, Y., Liu, Y., Wang, J., Jiang, R., \& Xu, L. (2017). Teacher Support and Math Engagement: Roles of Academic Self-Efficacy and Positive Emotions. Educational Psychology, 1-15. https://doi.org/10.1080/01443410.2017.1359238

Luszczynska, A., Gutiérrez-Doña, B., \& Schwarzer, R. (2005). General SelfEfficacy in Various Domains of Human Functioning: Evidence from Five Countries. International Journal of Psychology, 40(2), 80-89. 
https://doi.org/10.1080/00207590444000041

Malecki, C. K., \& Demaray, M. K. (2002). Measuring Perceived Social Support:

Development of the Child and Adolescent Social Support Scale (CASSS).

Psychology in the Schools, 39(1), 1-18. https://doi.org/10.1002/pits.10004

Malecki, C. K., \& Demaray, M. K. (2003). What Type of Support Do They Need? Investigating Student Adjustment as Related to Emotional, Informational, Appraisal, and Instrumental Support. 18(3), 231-252.

Malecki, C. K., \& Elliot, S. N. (1999). Adolescents Rating of Perceived Social Support and Its Importance: Validation of The Students Social Support Scale. Psychology in the Schools, 36(6), 475-483.

Malkoç, A., \& Mutlu, A. K. (2018). Academic Self-Efficacy and Academic Procrastination: Exploring the Mediating Role of Academic Motivation in Turkish University Students. Universal Journal of Educational Research, 6(10), 2087-2093. https://doi.org/10.13189/ujer.2018.061005

Mana, A., Saka, N., Dahan, O., Ben-Simon, A., \& Margalit, M. (2020). Implicit Theories, Social Support, and Hope as Serial Mediators for Predicting Academic Self-Efficacy Among Higher Education Students. Learning Disability Quarterly. https://doi.org/10.1177/0731948720918821

Pantu, E. A. (2021a). Moderasi Usia dalam Pengaruh Semester Terhadap Efikasi Diri Akademik pada Pembelajaran Online. Psikostudia, 10(1), 7889. https://doi.org/10.30872/psikostudia

Pantu, E. A. (2021b). Online Learning : The Role of Academic Self-Efficiency in Creating Academic Flow. Psychological Research and Intervention, 4(1), 1-8. https://doi.org/10.21831/pri.v4i1.40381

Peechapol, C., Na-Songkhla, J., Sujiva, S., \& Luangsodsai, A. (2018). An Exploration of Factors Influencing Self-efficacy in Online Learning: A Systematic Review. International Journal of Emerging Technologies in Learning, 13(9), 64-86. https://doi.org/10.3991/ijet.v13i09.8351

Pellerone, M. (2021). Self-Perceived Instructional Competence, Self-Efficacy 
and Burnout during the Covid-19 Pandemic: A Study of a Group of Italian School Teachers. European Journal of Investigation in Health, Psychology, and Education, 496-512. https://doi.org/https://doi.org/10.3390/ ejihpe11020035

Permatasari, N., Ashari, F. R., \& Ismail, N. (2021). Contribution of Perceived Social Support (Peer, Family, and Teacher) to Academic Resilience during COVID-1. Golden Ratio of Social Science and Education, 1(1), 1-12. https://doi.org/https://doi.org/10.52970/grsse/index

Permatasari, N., Sutanto, L., \& Ismail, N. S. (2021). Hubungan Efikasi Diri Terhadap Tingkat Kejenuhan Akademik: Studi Empiris Pembelajaran Daring Semasa Covid-19. Jurnal Sosio Sains, 7(1), 36-50.

Prihastyanti, I., \& Sawitri, D. R. (2018). Dukungan Guru Dan Efikasi Diri Akademik Pada Siswa Sma Semesta Semarang. Empati, 7(3), 33-46.

Rahmadina, N. A., Sulistiyana, \& Arsyad, M. (2020). Kontribusi Dukungan Sosial dan Efikasi Diri Terhadap Prokrastinasi Akademik Pada Siswa Kelas VII Di SMP Negeri 27 Banjarmasin. Jurnal Bimbingan Dan Konseling Ar-Rahman, 6(2), 83-87.

Schunk, D. H., \& Dibenedetto, M. K. (2016). Handbook of Motivation at School. In K. R. Wentzel \& D. B. Miele (Eds.), Handbook of Motivation at School. Routledge. https://doi.org/10.4324/9781315773384.ch3

Schunk, D. H., \& Pajares, F. (2002). The Development of Academic SelfEfficacy. In A. Wigfield \& J. Eccles (Ed.), Development of Achievement Motivation. Academic Press.

Shofia, A. (2021). Validasi Modul Pelatihan Komunikasi Interpersonal untuk Meningkatkan Efikasi diri Orang Tua dalam Berkomunikasi dengan Remaja di Lingkungan Berisiko. Gadjah Mada University.

Singh, V., \& Thurman, A. (2019). How Many Ways Can We Define Online Learning? A Systematic Literature Review of Definitions of Online Learning (1988-2018). American Journal of Distance Education, 33(4), 289-306. https://doi.org/10.1080/08923647.2019.1663082 
Sugiyono. (2018). Metode Penelitian Pendidikan (Pendekatan Kuantitatif, Kualitatif dan R\&D). Penerbit Alfabeta.

Svartdal, F., Sæle, R. G., Dahl, T. I., Nemtcan, E., \& Gamst-Klaussen, T. (2021).

Study Habits and Procrastination: The Role of Academic Self-Efficacy.

Scandinavian Journal of Educational Research, o(0), 1-20. https://doi.org/10.1080/00313831.2021.1959393

Tardy, C. H. (1985). Social Support Measurement. American Journal of Community Psychology, 13(2), 187-202. https://doi.org/10.1007/BF00905728

Tsuroya, F. I. (2020). Dampak Pembelajaran Online di Tengah Pandemi Covid-19 Terhadap Proses Pembelajaran Metode Yanbu'a di Kelas 2 MI At-Taqwa Bondowoso. IQ (Ilmu Al-Qur'an): Jurnal Pendidikan Islam, 3(2), 199-214. https://doi.org/10.37542/iq.v3i02.124

Tuaputimain, H. (2021). Korelasi Antara Efikasi Diri dengan Prokrastinasi Akademik di Kalangan Mahasiswa. Jurnal Teologi Berita Hidup, 4(1), 180-191.

Tus, J. (2021). Amidst the Online Learning in the Philippines: The Parental Involvement and Its Relationship to the Student's Academic Performance $\mathrm{x}$ Issue 3 AMIDST THE ONLINE LEARNING IN THE PHILIPPINES: THE. International Engineering Journal for Research \& Development, 6(3), 1-15.

Wills, T. A., \& Shinar, O. (2000). Measuring Perceived and Received Social Support. In Social Support Measurement and Intervention (pp. 86-90). Oxford University Press. https://doi.org/10.1093/med:psych/9780195126709.001.0001

Winemiller, D. R., Mitchell, E., Sutliff, J., \& Cline, D. J. (1987). Measurement Strategies in Social Support: a Descriptive Review of the Literature. 638648.

Wistarini, N. N. I., \& Marheni, A. (2018). Peran Dukungan Sosial Keluarga dan Efikasi Diri Terhadap Stres Akademik Mahasiswa Baru Fakultas 
Kedokteran Universitas Udayana Angkatan 2018. Jurnal Psikologi Udayana, 164-173.

Yates, A., Starkey, L., Egerton, B., \& Flueggen, F. (2021). High school students' experience of online learning during Covid-19: the influence of technology and pedagogy. Technology, Pedagogy, and Education, 30(1), 59-73. https://doi.org/10.1080/1475939X.2020.1854337

Yazid, H., \& Neviyarni. (2021). Pengaruh Pembelajaran Daring Terhadap Psikologis Siswa Terdampak Social Distancing Akibat Covid-19. Jurnal Human Care, Vol. 6(1), 207-213.

Yokoyama, S. (2019). Academic Self-Efficacy and Academic Performance in Online Learning: A Mini-Review. Frontiers in Psychology, 9(Januari 2019), 1-4. https://doi.org/10.3389/fpsyg.2018.02794

Yuri, N. P., \& Yendi, F. M. (2020). The Relationship of Peer Social Support with Academic Self Efficacy. NeoKonseling, 2(3), 1-7. https://doi.org/10.24036/00294kons2020

Zander, L., Brouwer, J., Jansen, E., Crayen, C., \& Hannover, B. (2018). Learning and Individual Differences Integration in Academic and Social Support Networks. Learning and Individual Differences, 62(January), 98-107.

Zed, M. (2014). Metode Penelitian Kepustakaan (Edisi III). Pustaka Obor Indonesia.

Zhou, J., \& Yu, H. (2021). Contribution of Social Support to Home-Quarantined Chinese College Students' Well-being during the COVID-19 Pandemic: the Mediating Role of Online Learning Self-efficacy and Moderating Role of Anxiety. Social Psychology of Education, 0123456789. https://doi.org/https://doi.org/10.1007/s11218-021-09665-4 Contribution 